\title{
Intracellular Calcium Transients and Potassium Current Oscillations Evoked by Glutamate in Cultured Rat Astrocytes
}

\author{
Jianguo Chen, Kurt H. Backus, and Joachim W. Deitmer \\ Abteilung für Allgemeine Zoologie, FB Biologie, Universität Kaiserslautern, D-67653 Kaiserslautern, Germany
}

Glutamate responses in cultured rat astrocytes from cerebella of neonatal rats were investigated using the perforated-patch configuration to record membrane currents without rundown of intracellular messenger cascades, and microfluorometric measurements to measure the intracellular $\mathrm{Ca}^{2+}$ concentration $\left(\left[\mathrm{Ca}^{2+}\right]_{\mathrm{i}}\right)$ and intracellular $\mathrm{pH}\left(\mathrm{pH}_{\mathrm{i}}\right)$ with fura-2 AM and $2^{\prime}, 7^{\prime}-$ bis-(2-carboxyethyl)-5,6-carboxyfluorescein acetoxy methylester respectively. In the perforated-patch mode, glutamate evoked single or multiple outward current transients in $82 \%$ of the cells, which disappeared when the recording technique was converted into a conventional whole-cell mode. The outward current transients were accompanied by $\left[\mathrm{Ca}^{2+}\right]_{\mathrm{i}}$ transients, whereas $\mathrm{pH}_{\mathrm{i}}$ fell monophasically, without any sign of oscillation. Pharmacological analysis of the glutamate-induced responses indicated that ionotropic receptor activation evoked an inward current but no outward current transients, and metabotropic receptor activation (of the mGluR1/5 type) elicited outward current transients but no inward current. The outward current transients were reduced in frequency, or even abolished, after depletion of the intracellular $\mathrm{Ca}^{2+}$-stores by the $\mathrm{Ca}^{2+}$-ATPase inhibitor cyclopiaconic acid $(10 \mu \mathrm{M})$. They reversed near -85 $\mathrm{mV}$ and were reduced by tetraethylammonium (10 mm), suggesting that they were caused by $\mathrm{K}^{+}$channel activation. It is concluded that glutamate evoked these $\mathrm{K}^{+}$outward current transients by oscillatory $\mathrm{Ca}^{2+}$ release mediated by mGluR activation. The corresponding membrane potential waves across the astroglial syncytium could provide spatial and temporal dynamics to the glial $\mathrm{K}^{+}$uptake capacity and other voltage-dependent processes.

Key words: glutamate; perforated patch-clamp; gramicidin; current oscillation; $\left[\mathrm{Ca}^{2+}\right]_{i}$ oscillations; $\mathrm{Ca}^{2+}$-activated $\mathrm{K}^{+}$ channels; rat
Changes in the intracellular $\mathrm{Ca}^{2+}$ concentration $\left(\left[\mathrm{Ca}^{2+}\right]_{\mathrm{i}}\right)$ play a crucial role in many processes involved in the modulation of signal transduction, development, and plasticity in the CNS. At present, multiple pathways have been demonstrated that can lead to $\left[\mathrm{Ca}^{2+}\right]_{\mathrm{i}}$ changes. The involvement of glutamate receptors appears to play a key role. The activation of glutamate receptors can change $\left[\mathrm{Ca}^{2+}\right]_{\mathrm{i}}$ by two distinct mechanisms. First, receptors of the ionotropic subclass, namely NMDA and a subpopulation of $\mathrm{Ca}^{2+}$-permeable AMPA/kainate receptors, directly mediate a $\mathrm{Ca}^{2+}$ influx. Second, receptors of the metabotropic glutamate receptor subclass (mGluR), e.g., the mGluR1 and mGluR5, induce the hydrolysis of phosphatidylinositol that leads to the inositol triphosphate $\left(\mathrm{IP}_{3}\right)$-mediated release of $\mathrm{Ca}^{2+}$ from intracellular stores. In addition, the membrane depolarization mediated by ionotropic glutamate receptors could activate voltage-dependent $\mathrm{Ca}^{2+}$-channels that allow $\mathrm{Ca}^{2+}$ influx.

Glial cells express ionotropic glutamate receptors in culture (Bowman and Kimelberg, 1984; Kettenmann et al., 1984) and in situ (Berger et al., 1992; Müller et al., 1992; Seifert and Steinhäuser, 1995). In cultured cerebellar fusiform cells (Burnashev et al., 1992), in cerebellar Bergmann glial cells in situ (Müller et al., 1992), in hippocampal glial cells in the CA1 region of the stratum

Received May 21, 1997; revised July 17, 1997; accepted July 18, 1997.

This study was supported by a grant of the Deutsche Forschungsgemeinschaft to J.W.D. and K.H.B. (De 231/11-1). We thank C. Lohr for critically reading this manuscript. We are grateful to Sandra Bergstein for her excellent technical assistance.

Reprint requests should be addressed to Dr. J. W. Dietmer, Abteilung für Allgemeine Zoologie, FB Biologie, Universität Kaiserslautern, Postfach 3049, D-67653 Kaiserslautern, Germany.

Dr. Chen's present address: II. Physiologisches Institut de Universität Heidelberg, Im Neuenheimer Feld 326, D-69120 Heidelberg, Germany.

Copyright (C) 1997 Society for Neuroscience $0270-6474 / 97 / 177278-10 \$ 05.00 / 0$ radiatum (Jabs et al., 1994), and in hilar glial precursor cells (Backus and Berger, 1995), evidence was found that the activation of AMPA/kainate receptors can also result in a $\mathrm{Ca}^{2+}$ influx.

Monophasic and multiple intracellular $\mathrm{Ca}^{2+}$ transients were observed in cultured astrocytes after the application of glutamate receptor agonists (Glaum et al., 1990; Jensen and Chiu, 1990, 1991; de Barry et al., 1991; Holzwarth et al., 1994; Brune and Deitmer, 1995). The pharmacological profile of these responses revealed that both $\mathrm{Ca}^{2+}$ influx and intracellular $\mathrm{Ca}^{2+}$ release were responsible for the $\mathrm{Ca}^{2+}$ transients. Recent results suggested that glial cells might communicate with each other, or with neurons, using waves of $\mathrm{Ca}^{2+}$ elevation that spread via gap junctions through the astrocytic syncytium. $\mathrm{Ca}^{2+}$ waves were propagated between glutamate-stimulated cells (Cornell-Bell et al., 1990; Charles et al., 1991), indicating the occurrence of a long-range oscillatory signaling mechanism in glial cells. In hippocampal astrocytes, waves of $\left[\mathrm{Ca}^{2+}\right]_{i}$ could be induced by the activity of neighboring neurons (Dani et al., 1992). Focal electrical stimulation of astrocytes in mixed cultures of rat forebrain cells induced intercellular $\mathrm{Ca}^{2+}$ waves and large increases in $\left[\mathrm{Ca}^{2+}\right]_{\mathrm{i}}$ in neighboring neurons, suggesting the existence of glialneuronal signaling pathways (Nedergaard, 1994).

Astrocytes express a large repertoire of voltage- and ligandgated ion channels, e.g., $\mathrm{Ca}^{2+}$-activated $\mathrm{K}^{+}$channels (Quandt

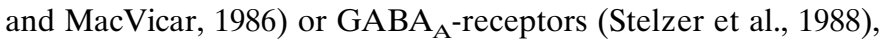
which are sensitive to changes in $\left[\mathrm{Ca}^{2+}\right]_{\mathrm{i}}$. Because the cytosol is dialyzed rapidly during conventional whole-cell clamp recordings, we used the perforated patch-clamp technique to characterize the membrane responses evoked by glutamate receptor agonists. In combination with the fluorescent imaging technique to measure $\left[\mathrm{Ca}^{2+}\right]_{\mathrm{i}}$ and $\mathrm{pH}_{\mathrm{i}}$, we could show in single cells that the application 
of agonists of glutamate receptors evoked oscillations of membrane currents associated with multiple $\left[\mathrm{Ca}^{2+}\right]_{i}$ transients.

A preliminary report of some of the results has been published previously in abstract form (Chen et al., 1997).

\section{MATERIALS AND METHODS}

Cell culture. For preparing primary cultured astrocytes, the cerebellar hemispheres of newborn rats $(\mathrm{P} 0-\mathrm{P} 1)$ were rapidly removed. Cells were isolated and cultured according to the method described by Fischer (1984). Immunohistochemical staining confirmed that the cultures consisted of enriched $(>95 \%)$ glial fibrillary acidic protein-positive astrocytes (Brune et al., 1994). After the cells had reached confluence, oligodendrocytes and macrophages were removed by a shaking procedure, and the remaining cells were dissociated, plated on glass coverslips coated with poly-D-lysine, and incubated in $7 \% \mathrm{CO}_{2}$ at $37^{\circ} \mathrm{C}$. The experiments were performed between 2 and $15 \mathrm{~d}$ after plating of the astrocytes at room temperature $\left(\sim 22-24^{\circ} \mathrm{C}\right)$.

Experimental setup. For perforated patch-clamp recordings, the culture dish was mounted on the stage of an inverted microscope (Zeiss). For the combined electrophysiological and microfluorometric experiments, the culture dish was mounted on an inverted fluorescence microscope (Diaphot, Nikon, Tokyo, Japan) equipped with a Nikon CF-Fluor $20 \times$ objective. Recording patch pipettes were pulled from borosilicate glass, and the tips were fire-polished (resistance 4-6 M $\Omega$, when filled with the pipette solution). Gramicidin-perforated-patch recordings were performed following the method of Kyrozis and Reichling (1995). Briefly, the electrode tip was filled for 1-40 sec with the gramicidin-free pipette solution (see below) to avoid problems with seal formation, and then back-filled with the gramicidin-containing pipette solution. After the formation of a gigaseal (on-cell recording) (Hamill et al., 1981), short steps in holding potential were applied continuously at $2 \mathrm{~min}$ intervals to monitor the gradual decrease in series resistance. Drug application was not started until the series resistance decreased below $50 \mathrm{M} \Omega$, which usually lasted $20-30 \mathrm{~min}$. The reference potential for all measurements was the zero-current potential of the pipette in the bath before establishment of the gigaseal.

Currents were recorded by an EPC-7 (List, Darmstadt, Germany) patch-clamp amplifier. Before digitization (sampling rate $0.5-1 \mathrm{kHz}$ ), currents were filtered at $3 \mathrm{kHz}$ with a three-pole low-pass Bessel filter. Data were stored and evaluated with the aid of the PCLAMP hardware and software package (Axon Instruments, Foster City, CA) for a personal computer. To determine the agonist-induced current amplitudes, the maximal deflection from the baseline was used. The difference of two samples was tested using the two-tailed $t$ test.

Microfluorometric recordings. The fluorescence microscope was equipped with a dual excitation fluorometric imaging system (PTI, Wedel, Germany). The illumination was generated by a $75 \mathrm{~W}$ xenon bulb. Monochromator settings, chopper frequency, and complete data acquisition were controlled by software (PTI) for microcomputer systems. Astrocytes were loaded by incubating the cell cultures in $2^{\prime}, 7^{\prime}$-bis-(2carboxyethyl)-5,6-carboxyfluorescein-acetoxy-methylester (BCECF-AM; $25 \mu \mathrm{M})$ for $20 \mathrm{~min}$ or fura-2 $\mathrm{AM}(5 \mu \mathrm{M})$ for $60 \mathrm{~min}$ at room temperature. Dye-loaded astrocytes were excited by monochromatic light at wavelengths 350 and $380 \mathrm{~nm}$ (fura-2 AM) to measure $\left[\mathrm{Ca}^{2+}\right]_{\mathrm{i}}$ or at 440 and $495 \mathrm{~nm}$ (BCECF-AM) to measure $\mathrm{pH}_{\mathrm{i}}$. The fluorescence emission of the cell under perforated-patch control, of another single cell, and the emission of a selected area with a group of 5-10 cells on the coverslip was recorded simultaneously with a video camera (SIT C-2400, Hamamatsu, Garching, Germany), using a $495 \mathrm{~nm}$ longpass filter for fura-2 AM and a $520 \mathrm{~nm}$ longpass filter for BCECF-AM. The signals were sampled at 3 $\mathrm{Hz}$ and computed into relative ratio units. Drug-induced changes of $\left[\mathrm{Ca}^{2+}\right]_{\mathrm{i}}$ were measured by determining the changes of the fluorescence ratio of $350 \mathrm{~nm}: 380 \mathrm{~nm}$. The BCECF-AM ratio of $440 \mathrm{~nm}$ : $495 \mathrm{~nm}$ was converted into $\mathrm{pH}$ units according to calibration described by Brune et al. (1994).

Solutions and drug application. The pipette solution for perforated patch-clamp recordings contained (in $\mathrm{mM}$ ): $\mathrm{KCl} 140, \mathrm{NaCl} 5, \mathrm{CaCl}_{2} 0.5$, $\mathrm{MgCl}_{2}$ 1, EGTA 5, HEPES 10; $\mathrm{pH}$ adjusted to 7.2 with KOH. Gramicidin (Sigma, St. Louis, MO), $5 \mathrm{mg} / \mathrm{ml}$, was dissolved in dimethylsulfoxide (DMSO), vortexed for $1 \mathrm{~min}$, sonicated for $20 \mathrm{sec}$, and then added to the pipette solution to give a final concentration of $25-50 \mu \mathrm{g} / \mathrm{ml}$. In some cells the conventional whole-cell configuration was established after recording in the gramicidin-perforated-patch configuration. This re- sulted in a dialysis of the cell interior with the pipette solution listed above.

During the experiments the cell cultures were superfused continuously with a HEPES-buffered saline containing (in $\mathrm{mM}$ ): $\mathrm{NaCl} \mathrm{145,} \mathrm{KCl} 5$, $\mathrm{CaCl}_{2} 2, \mathrm{MgCl}_{2}$ 1, glucose 10, HEPES 10; $\mathrm{pH}$ adjusted to 7.4 with $\mathrm{NaOH}$. In a few experiments we used a $\mathrm{Ca}^{2+}$-free salt solution in which $\mathrm{CaCl}_{2}$ was replaced by EGTA $(1 \mathrm{~mm})$. Stock solutions of glutamate, quisqualate (100 mM in aqua bidest; both from Sigma), and kainate (100 $\mathrm{mm}$ in $100 \mathrm{~mm} \mathrm{NaOH}$; Sigma) were prepared. Stock solutions of cyclopiazonic acid (CPA, $50 \mathrm{~mm}$; Sigma) and 6-cyano-7-nitroquinoxaline-2,3dione (CNQX, $50 \mathrm{~mm}$; Tocris Cookson, Bristol, UK) were dissolved in DMSO and stored at $-20^{\circ} \mathrm{C}$. Kynurenic acid (Sigma) was dissolved in the saline in the final concentration. Stock solutions of trans- $( \pm)-1-$ aminocyclopentane-1S,3R-dicarboxylic acid (t-ACPD; $20 \mathrm{~mm}$ in $50 \mathrm{~mm}$ $\mathrm{NaOH}$ ), (s) 3,5 dihydroxyphenyl-glycine (DHPG; $100 \mathrm{~mm}$ in aqua bidest), and L-2-amino-4-phosphonobutyric acid (L-AP4; $20 \mathrm{~mm}$ in $50 \mathrm{~mm}$ $\mathrm{NaOH}$ ) were prepared. t-ACPD, DHPG, and L-AP4 were purchased from Tocris Cookson. All other drugs were obtained from Sigma. Drugs were added to the saline shortly before use in defined concentrations. Fura-2 AM and BCECF-AM were obtained from Molecular Probes (Eugene, OR).

\section{RESULTS}

\section{Glutamate evokes membrane current oscillations}

The whole-cell membrane current of cultured cerebellar astrocytes was recorded in the gramicidin-perforated-patch configuration at a holding potential $\left(V_{\mathrm{h}}\right)$ of $-70 \mathrm{mV}$. In these cells $1 \mathrm{~mm}$ glutamate, applied by bath superfusion for $10 \mathrm{sec}$, evoked different current response patterns (Fig. 1). All of them showed a distinct inward current $(100 \%$ of the cells; $n=62)$, but they differed in the frequency, shape, and time course of oscillating outward current transients (Fig. $1 A-C, E$ ) that were superimposed in most cells $(82 \% ; n=51)$.

In 29 cells, multiple outward current transients (2-8) (Fig. $1 A, E)$ were observed after glutamate application. Although the first outward current transient usually had the largest amplitude $(41 \pm 25 \mathrm{pA}$; mean $\pm \mathrm{SD})$, the subsequent transients showed a continuous but slow decrease in amplitude with time. When the glutamate application was prolonged until up to $3 \mathrm{~min}$, the outward current transients persisted for several minutes (data not shown). In some cells (16 of 62), only a single outward current transient with a mean amplitude of $22 \pm 14 \mathrm{pA}$ was superimposed onto the rising phase of the inward current component (Fig. $1 B$ ). No outward current transients were present in 11 of 62 cells, i.e., in $18 \%$ of the astrocytes (Fig. 1C). A few astrocytes $(n=6)$ showed a mixed response where single and multiple outward current transients could change from one to the next glutamate application and vice versa. The presence of multiple current oscillations in astrocytes showed a remarkable persistency, because they could be observed for up to $1 \mathrm{hr}$ without any major changes in shape, number, and amplitude of the current transients (Fig. 1E).

Membrane current oscillations induced by glutamate, however, could be observed only in the gramicidin-perforated-patch configuration. Astrocytes exposed to glutamate $(1 \mathrm{~mm} ; 10 \mathrm{sec})$ in the conventional whole-cell clamp configuration responded with an inward current of $28 \pm 7.5 \mathrm{pA}(n=35)$ (Fig. 1D) that was significantly $(p<0.01)$ larger than that recorded in the gramicidin-perforated-patch configuration but never showed any outward current oscillations. In eight cells that showed outward current transients after glutamate application in the gramicidinperforated-patch configuration, the membrane patch was ruptured carefully to establish the conventional whole-cell clamp configuration. After this procedure the glutamate-induced outward current transients disappeared completely (Figs. 2, 3, top 

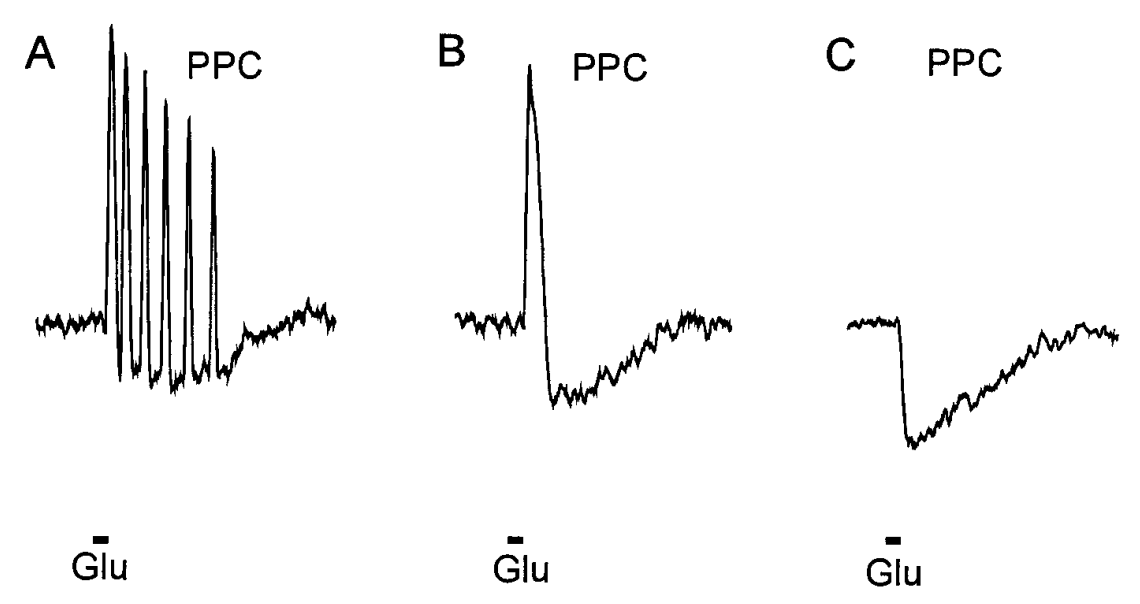

D WCC

Gīu

Giu

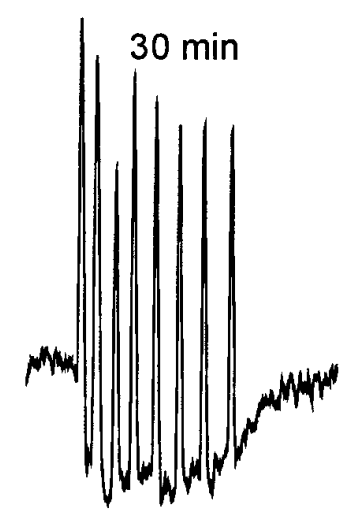

Glu

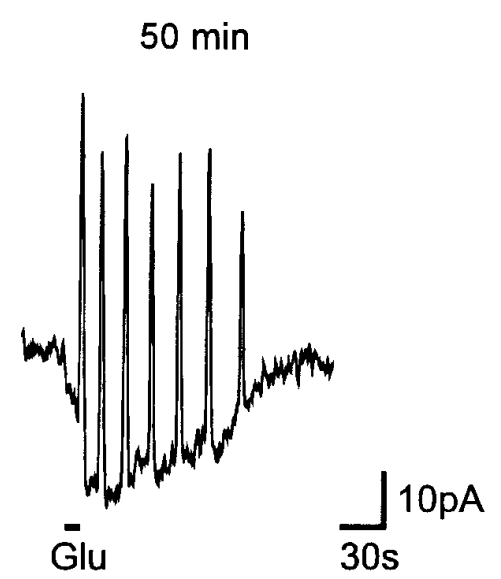

Figure 1. Glutamate-induced current response patterns in cultured cerebellar astrocytes. $A-C$, The membrane current was recorded in the gramicidinperforated-patch configuration $(P P C)$, and glutamate $(G l u, 1 \mathrm{mM})$ was applied by bath application for $10 \mathrm{sec}$ as indicated. Glutamate evoked an inward current that was superimposed by multiple $(A)$, a single $(B)$, or no outward current transients $(C)$. $D$, In the conventional whole-cell clamp configuration $(W C C)$, glutamate exclusively induced an inward current without showing any outward current transients. $E$, Gramicidin-perforated-patch recording that demonstrates the persistency of outward current transients in time.

traces), indicating the requirement of a functionally intact cytosol for the occurrence of current oscillations in astrocytes as revealed by the gramicidin-perforated-patch configuration.

\section{Simultaneous measurement of $\left[\mathrm{Ca}^{2+}\right]_{i}, \mathrm{pH}_{\mathrm{i}}$, and membrane current oscillations}

Recently it was reported that the application of glutamate on astrocytes could evoke transient and complex oscillatory changes in $\left[\mathrm{Ca}^{2+}\right]_{\mathrm{i}}$ (Cornell-Bell et al., 1990; Glaum et al., 1990; Jensen and Chiu, 1990, 1991; de Barry et al., 1991; Dani et al., 1992; Holzwarth et al., 1994; Brune and Deitmer, 1995) and considerable increases in the intracellular $\mathrm{H}^{+}$concentration (Brune and Deitmer, 1995). Because these experiments were performed exclusively in intact cells, we supposed that the glutamate-induced current oscillation we observed in the gramicidin-perforatedpatch configuration could be mediated by changes in $\left[\mathrm{Ca}^{2+}\right]_{i}$ or $\mathrm{pH}_{\mathrm{i}}$, or both. To examine this issue, the changes in $\left[\mathrm{Ca}^{2+}\right]_{\mathrm{i}}$ or $\mathrm{pH}_{\mathrm{i}}$ were recorded simultaneously with the membrane current in the perforated-patch and conventional whole-cell mode.

Glutamate (1 $\mathrm{mm})$ evoked a large inward current that was superimposed by a number of distinct outward current transients (Fig. 2). In the same cell we observed an equal number of transient $\left[\mathrm{Ca}^{2+}\right]_{\mathrm{i}}$ changes that were temporally associated with the outward current transients. In addition, a small increase in basal $\left[\mathrm{Ca}^{2+}\right]_{\mathrm{i}}$ was observed that followed roughly the time course of the deactivating inward current component. In cells that responded only with a single outward current transient, only a single large $\mathrm{Ca}^{2+}$ transient was also apparent (Fig. 3). When the whole-cell clamp configuration was subsequently established in the same cell $(n=4)$, both outward current and multiple $\mathrm{Ca}^{2+}$ transients disappeared, leaving a strongly reduced single initial $\mathrm{Ca}^{2+}$ transient and a small tonic increase in basal $\left[\mathrm{Ca}^{2+}\right]_{\mathrm{i}}$ (Figs. 2,3 , top right and middle right traces). Also in two cells in which glutamate failed to induce current oscillations in the perforatedpatch configuration, no $\mathrm{Ca}^{2+}$ transients were observed.

Changes in $\left[\mathrm{Ca}^{2+}\right]_{\mathrm{i}}$ in a group of neighboring astrocytes, which were not in contact with the patch pipette, are shown in the bottom traces of Figures 2 and 3. In these cells glutamate also induced changes in $\left[\mathrm{Ca}^{2+}\right]_{i}$, but oscillations were not observed, indicating that the fura- 2 AM fluorescence signal reflected the integrated response of many cells that were not producing oscillations in phase. Rather, these presumed $\left[\mathrm{Ca}^{2+}\right]_{i}$ oscillations showed up as an initial transient and a sustained rise for $>1 \mathrm{~min}$ (Fig. 2) or a monophasic $\left[\mathrm{Ca}^{2+}\right]_{\mathrm{i}}$ rise (Fig. 3).

A small decrease in $\mathrm{pH}_{\mathrm{i}}$ could be measured in single astrocytes 


\section{Perforated patch-clamp $\longrightarrow$ Whole-cell clamp}

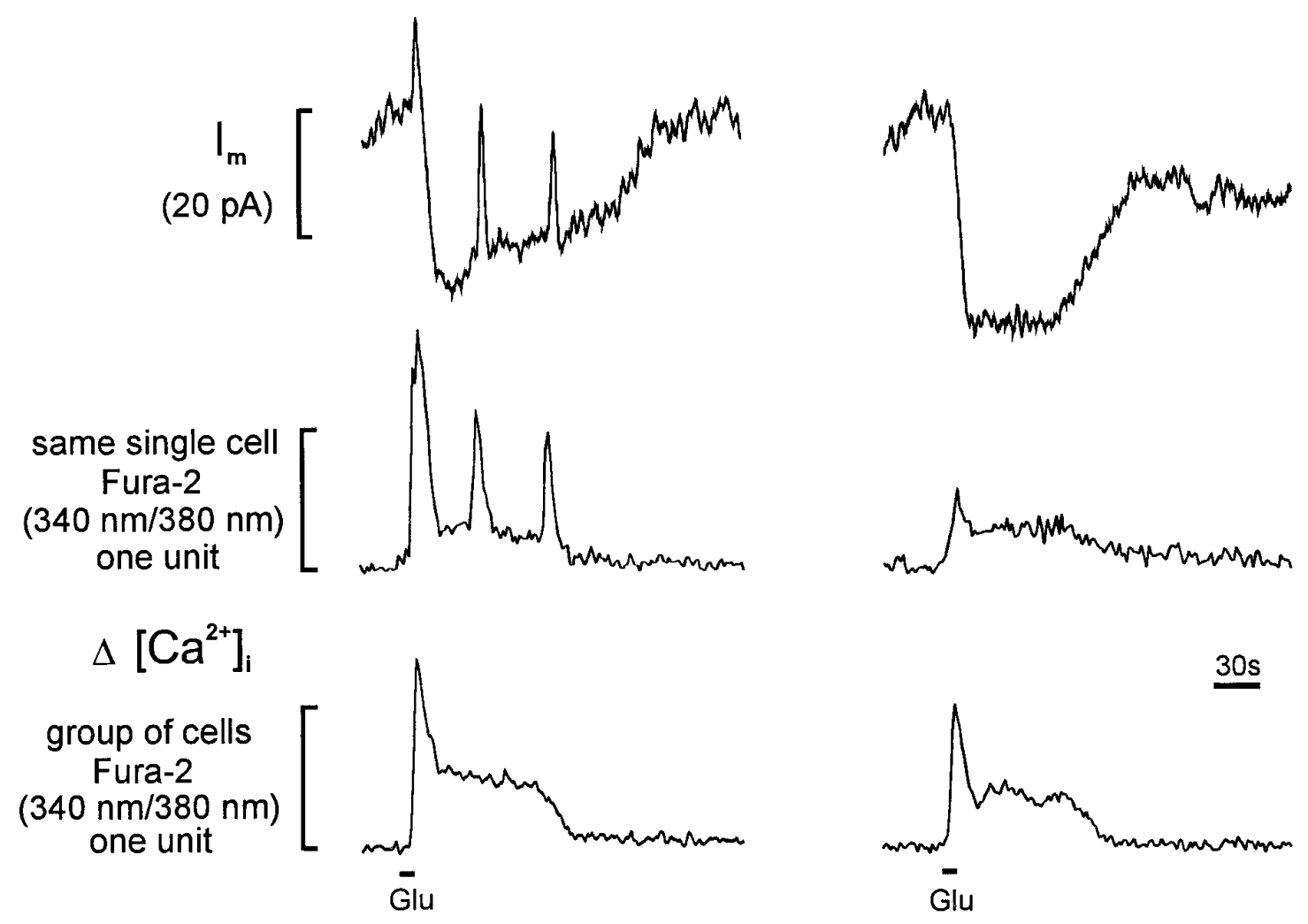

Figure 2. Simultaneous recording of membrane current and $\left[\mathrm{Ca}^{2+}\right]_{\mathrm{i}}$ using the digital imaging technique in fura-2 AM-loaded cerebellar astrocytes showing multiple outward current transients. Left column, Gramicidin-perforated-patch configuration: glutamate (Glu, $1 \mathrm{mM})$, applied for 10 sec as indicated, induced an inward membrane current that was superimposed by three outward current transients (top). Each outward current transient was preceded by a transient increase in $\left[\mathrm{Ca}^{2+}\right]_{\mathrm{i}}$ (middle). The bottom trace represents the averaged change in $\left[\mathrm{Ca}^{2+}\right]_{\mathrm{i}}$ induced by glutamate recorded from a group of cells in the vicinity of the cell displayed above. Right column, Responses of the same cells to glutamate after establishment of the conventional whole-cell clamp configuration.

in which $1 \mathrm{~mm}$ glutamate evoked outward current transients, but pH oscillations were never observed (Fig. 4). Similar results were obtained in single astrocytes or in groups of "unpatched" cells $(n=8)$, regardless of whether they showed multiple or single outward current transients (Fig. 4). These results suggested that there was probably no coupling between changes in $\mathrm{pH}_{\mathrm{i}}$ and the different current and $\left[\mathrm{Ca}^{2+}\right]_{\mathrm{i}}$ response patterns in these astrocytes.

\section{Effects of glutamate receptor ligands}

The absence of glutamate-induced outward current transients and $\left[\mathrm{Ca}^{2+}\right]_{i}$ oscillations in the whole-cell clamp configuration suggested the involvement of an intracellular messenger system, which was dialyzed in the conventional whole-cell mode but persisted in the perforated patch-clamp mode. Because we had observed a correlation in time between $\left[\mathrm{Ca}^{2+}\right]_{i}$ oscillations and outward current transients, we attempted to identify the glutamate receptor subtype and the mechanism underlying the membrane current oscillations by recording the membrane current in the gramicidin-perforated-patch configuration. The effects of different glutamate receptor ligands on $\left[\mathrm{Ca}^{2+}\right]_{i}$ and $\mathrm{pH}_{\mathrm{i}}$ in rat astrocytes had been studied previously (de Barry et al., 1991; Holzwarth et al., 1994; Brune and Deitmer, 1995).

Glutamate is a mixed agonist at both ionotropic receptors and mGluRs. Therefore, we tested separately an involvement of ionotropic and metabotropic receptors in the induction of current oscillations. Kainate ( $400 \mu \mathrm{M}, 10 \mathrm{sec}$ ), an agonist of the nonNMDA glutamate receptor subtype, evoked an inward current, but was unable to elicit outward current oscillations as did glutamate in the same cell $(n=5)$ (Fig. $5 A)$. Kynurenic acid ( $1 \mathrm{~mm}$; $n=4$ ) (Fig. $5 B)$, a broad-spectrum glutamate antagonist of ionotropic receptors (Perkins and Stone, 1982), and CNQX (50 $\mu \mathrm{M} ; n=4$ ) (Fig. 5C), a selective blocker of the AMPA/kainate receptor subtype (Honoré et al., 1988), reduced the glutamateevoked inward current but failed to block the glutamate-induced outward current transients (Fig. 5B,C).

Quisqualate, which is known to be an agonist of AMPA/ kainate as well as of mGluRs, evoked outward current transients but no detectable inward current when applied in a concentration of $200 \mu \mathrm{M}$ for $10 \mathrm{sec}(n=5)$ (Fig. $6 \mathrm{~A})$. The metabotropic agonist t-ACPD $(30 \mu \mathrm{M})$, an agonist reported to activate receptors of the mGluR2/3 subtype but that also exerted weak agonistic activity at mGluR1/5 receptors (Nakanishi, 1992; Tanabe et al., 1993), failed to evoke an inward current but elicited one or multiple outward current transients $(n=5)$ (Fig. 6B). DHPG $(100 \mu \mathrm{M})$, an agonist reported to be selective for mGluRs including the mGluR $1 / 5$ subtypes, also mimicked the glutamate-evoked outward current transients $(n=5)$ (Fig. $6 C)$. The agonist of receptors of the mGluR4/6-8 subtypes, L-AP4 (Nakanishi, 1992; Tanabe et al., 1993), however, had no effect on the membrane current in cultured astrocytes when applied at $200 \mu \mathrm{M}$ for $10 \mathrm{sec}(n=5)$ (Fig. 


\section{Perforated patch-clamp $\longrightarrow$ Whole-cell clamp}
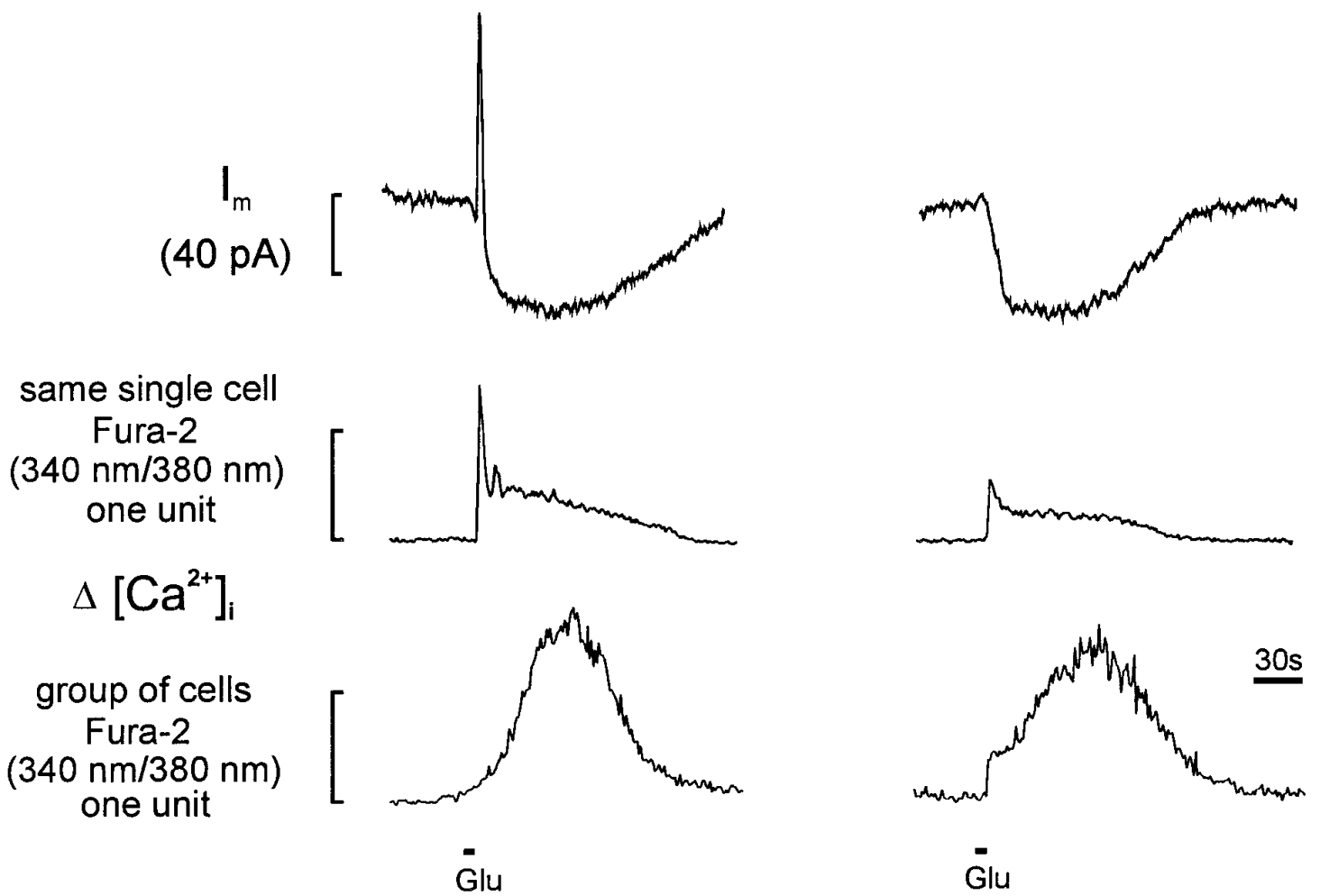

Figure 3. Simultaneous recording of membrane current and $\left[\mathrm{Ca}^{2+}\right]_{i}$ using the digital imaging technique in cerebellar astrocytes showing a single outward current transient. Left column, Gramicidin-perforated-patch configuration: glutamate (Glu, $1 \mathrm{~mm}$ ), applied for 10 sec as indicated, induced an inward membrane current that was superimposed by a single outward current transient (top). A transient increase in $\left[\mathrm{Ca}^{2+}\right]_{\mathrm{i}}$ was followed by a slowly decaying $\left[\mathrm{Ca}^{2+}\right]_{\mathrm{i}}$ decrease (middle). The bottom trace represents the averaged change in $\left[\mathrm{Ca}^{2+}\right]_{\mathrm{i}}$ induced by glutamate recorded from a group of cells in the vicinity of the cell displayed above. Right column, Responses of the same cells to glutamate after establishment of the conventional whole-cell clamp configuration.

$6 D)$. These results indicate that the outward current transients evoked by glutamate were attributable to the activation of mGluRs. The pharmacological profile of the glutamate-evoked outward current transients suggested the activation of mGluRs of the mGluR $1 / 5$ or mGluR2/3 subtypes.

\section{Contribution of intracellular $\mathbf{C a}^{2+}$ mobilization}

Glutamate receptors of the mGluR1/5 subtype are coupled via a G-protein to the hydrolysis of phosphatidylinositol, which results in the production of $\mathrm{IP}_{3}$ and the subsequent release of $\mathrm{Ca}^{2+}$ from $\mathrm{IP}_{3}$-sensitive intracellular stores (Berridge and Irvine, 1989). To test whether an intracellular $\mathrm{Ca}^{2+}$ release was involved in the activation of the glutamate-evoked outward current transients, intracellular $\mathrm{Ca}^{2+}$ stores were depleted using CPA $(10 \mu \mathrm{M})$, which was preapplied for $5 \mathrm{~min}$ and then in combination with glutamate $(1 \mathrm{~mm} ; n=5)$. CPA alone elicited a transient $\left[\mathrm{Ca}^{2+}\right]_{\mathrm{i}}$ rise, indicating reversible loss of $\mathrm{Ca}^{2+}$ from intracellular stores $(n=6)$.

In the presence of CPA the outward current transients evoked by glutamate were strongly reduced, usually to a single transient (Fig. $7 A$ ), or when it was preapplied for $10 \mathrm{~min}$, they were totally abolished (Fig. 7B). The inward current component, however, remained unaffected by CPA (Fig. 7). These results indicate that the current oscillations were likely mediated by the release of $\mathrm{Ca}^{2+}$ from intracellular, CPA-sensitive stores.

The contribution of an influx of extracellular $\mathrm{Ca}^{2+}$ to the glutamate-induced current oscillations was examined by comparing the current responses evoked in standard saline with those in a $\mathrm{Ca}^{2+}$-free saline that contained $1 \mathrm{~mm}$ EGTA. The initial outward current transient observed in standard salt solution was still prominent when glutamate was applied in $\mathrm{Ca}^{2+}$-free salt solution ( $n=8$; not shown). In cells expressing multiple current oscillations, however, no consistent effect of the $\mathrm{Ca}^{2+}$-free salt solution was observed. Usually the oscillatory outward current transients were reduced or disappeared completely $(n=6)$. In these cells, readdition of extracellular $\mathrm{Ca}^{2+}$ did not result in a recovery of outward current oscillations. The results suggest that the sustained outward current transients required the presence of extracellular $\mathrm{Ca}^{2+}$ to continue, but the large initial transient apparently did not depend on $\mathrm{Ca}^{2+}$ influx and was presumably caused by $\mathrm{Ca}^{2+}$ release from intracellular stores.

\section{Identification of the outward current transients}

To identify the type of ion channel underlying the glutamateinduced outward current transients we determined their reversal potential. Therefore, $1 \mathrm{~mm}$ glutamate was applied when $V_{\mathrm{hr}}$ was altered to more hyperpolarized values during the glutamateinduced inward current. As shown in Figure $8 A, B$, the outward current transients decreased or reversed their polarity at a holding potential of -90 or $-100 \mathrm{mV}$. The current amplitudes were fitted by linear regression to yield a rough estimate of the reversal potential of these outward current transients (Fig. 8C). The 


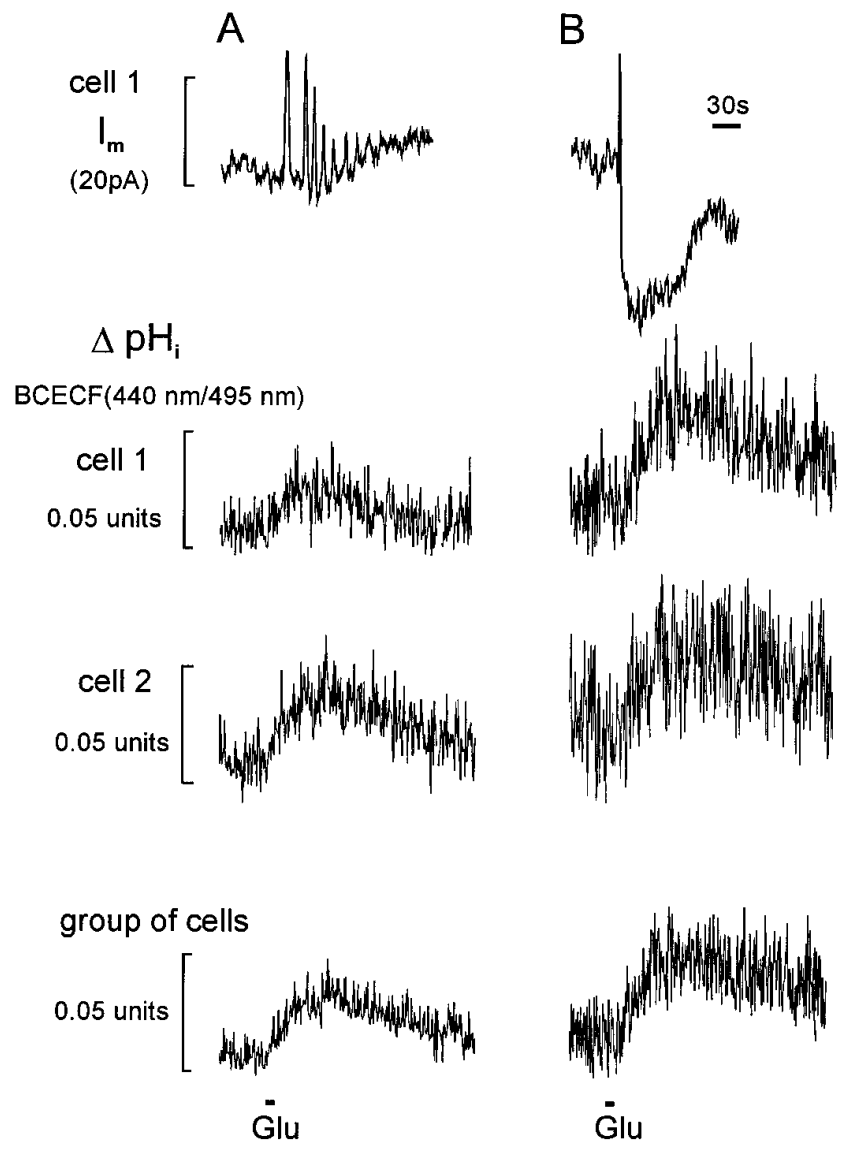

Figure 4. Simultaneous recording of membrane current in the gramicidin-perforated-patch configuration and $\mathrm{pH}_{\mathrm{i}}$ using the digital imaging technique in BCECF-AM-loaded cerebellar astrocytes. Top, Current responses induced by glutamate $(G l u, 1 \mathrm{~mm}$, applied for $10 \mathrm{sec}$ as indicated) of an astrocyte showing multiple outward current transients $(A)$ and another showing a single outward current transient $(B)$. Second row from top, Corresponding glutamate-induced $\mathrm{pH}_{\mathrm{i}}$ changes to the current traces on top. Third row from top, Simultaneous measurement of the glutamate-induced $\mathrm{pH}_{\mathrm{i}}$ change in another single cell in the vicinity that was not under perforated-patch control. Bottom, Simultaneous measurement of the glutamate-induced $\mathrm{pH}_{\mathrm{i}}$ change averaged over a group of cells in the vicinity. A decrease in $\mathrm{pH}_{\mathrm{i}}$ is displayed as an upward deflection.

resulting reversal potential of $-84.9 \mathrm{mV}(n=4)$ was close to the calculated $\mathrm{K}^{+}$equilibrium potential $\left(E_{\mathrm{K}^{+}}=-83 \mathrm{mV}\right)$, indicating the involvement of $\mathrm{K}^{+}$channels during the glutamate-evoked current transients.

This was confirmed by the sensitivity to tetraethylammonium (TEA) of the outward current transients. TEA $(10 \mathrm{~mm} ; n=5)$, a $\mathrm{K}^{+}$channel blocker (Rudy, 1988), reduced the outward current transients evoked by glutamate in cells showing multiple oscillations (Fig. 9A) and also in those with a single outward current transient (Fig. 9B).

\section{DISCUSSION}

\section{Perforated-patch recordings reveal glutamate-induced current oscillations}

To minimize the washout of regulatory molecules that could modulate ion channel activity (Korn et al., 1991), we have used perforated-patch recordings with gramicidin, which forms pores selective for monovalent cations but impermeable for anions and divalent cations (Myers and Haydon, 1972). The use of this
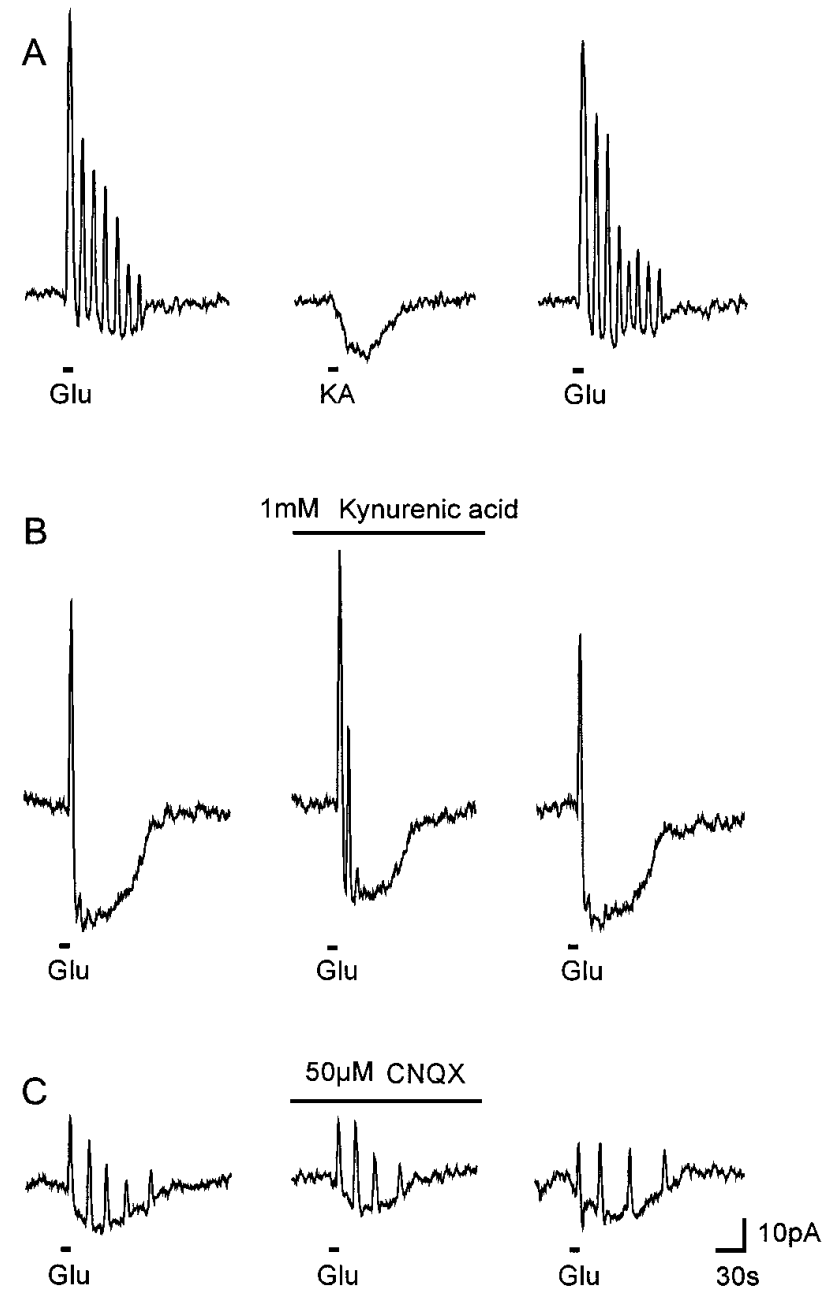

Figure 5. Effect of ionotropic glutamate receptor ligands. $A$, Kainate (KA, $400 \mathrm{~mm}$, applied for $10 \mathrm{sec}$ as indicated) did not elicit any current oscillation. $B$, Kynurenic acid (1 mM, preapplication time: $5 \mathrm{~min}$ ), and $C$, CNQX $(50 \mu \mathrm{M}$, preapplication time: $5 \mathrm{~min})$ reduced the glutamateinduced inward current but not the outward current transients.

technique revealed that glutamate receptor agonists evoked an inward current that was superimposed by a single or multiple outward current transients. Many preceding studies on glutamate receptors in glial cells in culture (Sontheimer et al., 1988; Usowicz et al., 1989; Wyllie and Cull-Candy, 1994) and in brain slices (Berger et al., 1992; Müller et al., 1992; Jabs et al., 1994; Backus and Berger, 1995; Seifert and Steinhäuser, 1995) missed the current oscillations, presumably because of the use of the conventional whole-cell clamp configuration. In another study in which the perforated-patch technique was used in hilar glial precursor cells, $\mathrm{Ca}^{2+}$-dependent $\mathrm{K}^{+}$channels were observed after $\mathrm{Ca}^{2+}$ influx through $\mathrm{Ca}^{2+}$-permeable AMPA/kainate receptors (Backus et al., 1995).

\section{Identification of the mGluR subtype}

The application of the ionotropic agonist kainate evoked an inward current but no superimposed outward current transients, whereas the mixed agonist quisqualate and agonists selective for mGluR subtypes, DHPG and t-ACPD, induced outward current transients but no inward current component. These findings, together with the lack of effect of blockers of ionotropic glutamate receptors, kynurenic acid and CNQX, indicate that the outward 

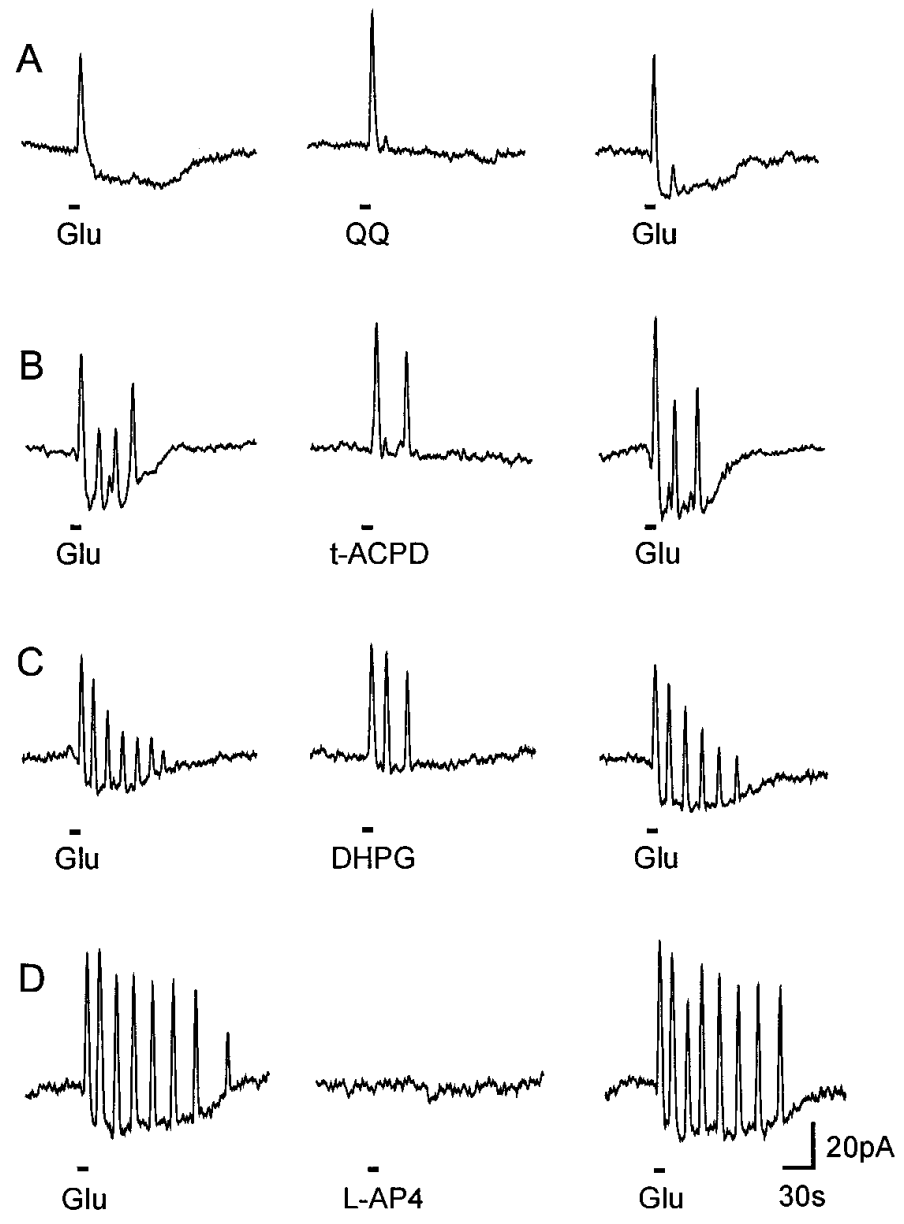

Figure 6. The effect of metabotropic glutamate receptor agonists. $A$, Quisqualate $(Q Q, 200 \mu \mathrm{M}$, applied for $10 \mathrm{sec}$ as indicated), $B$, t-ACPD (30 $\mu \mathrm{M}, 10 \mathrm{sec})$, and $C$, DHPG $(100 \mu \mathrm{M}, 10 \mathrm{sec})$ evoked outward current transients but no detectable inward currents. $D$, L-AP4 $(200 \mu \mathrm{M}, 10 \mathrm{sec})$ had no effect on the membrane current of cultured cerebellar astrocytes.

current transients were caused by the activation of mGluRs. The inward current component was evoked only by glutamate or kainate, in either conventional or perforated patch-clamp mode, but not by t-ACPD, DHPG, or L-AP4, indicating that it was mediated by ionotropic glutamate receptors, most likely of the AMPA/kainate subtype, which are expressed in astrocytes in culture (Sontheimer et al., 1988; Backus et al., 1989; Usowicz et al., 1989; Burnashev et al., 1992; Wyllie and Cull-Candy, 1994; Telgkamp et al., 1996) and in brain slices (Berger et al., 1992; Müller et al., 1992; Jabs et al., 1994; Backus and Berger, 1995; Seifert and Steinhäuser, 1995).

The pharmacological profile of mGluR subtypes (Nakanishi, 1992; Tanabe et al., 1993; Pin and Duvoisin, 1995) suggests that the induction of outward current transients by glutamate is mediated by the mGluR1/5 subtypes, because their selective agonist DHPG was effective. t-ACPD, an agonist of mGluR2/3 and mGluR1/5 subtypes (Pin and Duvoisin, 1995), was also effective. The selective mGluR4/6-8 agonist L-AP4 did not induce any response. Because the depletion of intracellular $\mathrm{Ca}^{2+}$-stores by CPA led to a reduction of outward current transients, it is likely that the mGluR subtype involved in the mechanism underlying the outward current oscillations is coupled to intracellular $\mathrm{Ca}^{2+}$ release. At present, mGluR1/5 receptors are the only mGluR

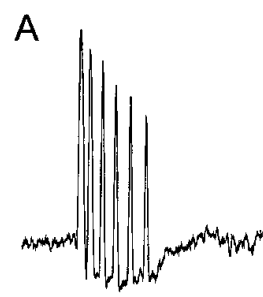

$\bar{G}$

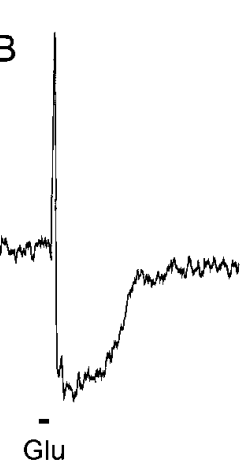

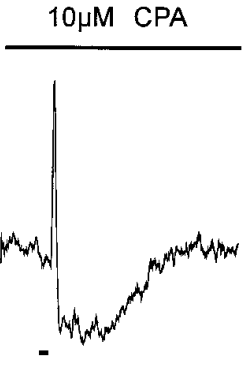

Glu

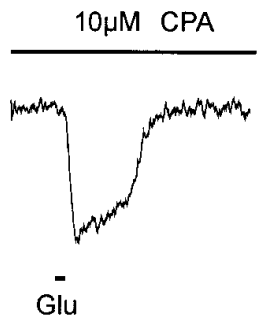

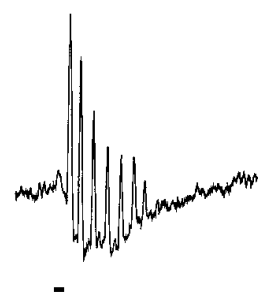

Glu
Figure 7. Effect of CPA on glutamate-induced currents in cultured cerebellar astrocytes. CPA $(10 \mu \mathrm{M}$, preapplied for $5 \mathrm{~min})$ inhibited the outward current transients induced by glutamate $(1 \mathrm{~mm}$, applied for $10 \mathrm{sec}$ as indicated) in cells responding with multiple oscillations $(A)$ or with a single oscillation $(B)$, but had no effect on the inward current component.

subtypes that are linked to the $\mathrm{IP}_{3}$-mediated intracellular $\mathrm{Ca}^{2+}$ mobilization (Abe et al., 1992; Aramori and Nakanishi, 1992). Therefore, mGluR1/5 receptors are likely involved in the induction of these outward current oscillations.

\section{Glutamate-induced $\left[\mathrm{Ca}^{2+}\right]_{\mathbf{i}}$ changes and oscillations}

Glial cells respond to various neurotransmitters with changes of $\left[\mathrm{Ca}^{2+}\right]_{\mathrm{i}}$. Monophasic changes in $\left[\mathrm{Ca}^{2+}\right]_{\mathrm{i}}$ are caused by an elevation of the extracellular $\mathrm{K}^{+}$concentration or by the activation of ionotropic receptor agonists, e.g., kainate (Jensen and Chiu, 1990; Salm and McCarthy, 1990; Brune and Deitmer, 1995) or GABA (Kirchhoff and Kettenmann, 1992). These responses are thought to be caused by an influx of $\mathrm{Ca}^{2+}$ through $\mathrm{Ca}^{2+}$-permeable ionotropic receptors or voltage-dependent channels (Finkbeiner, 1995). Polyphasic responses evoked by glutamate receptor agonists are characterized by sustained $\left[\mathrm{Ca}^{2+}\right]_{\mathrm{i}}$ oscillations preceded by an initial transient $\left[\mathrm{Ca}^{2+}\right]_{\mathrm{i}}$ rise that is caused primarily by a release of $\mathrm{Ca}^{2+}$ from $\mathrm{IP}_{3}$-sensitive intracellular stores (cf. Finkbeiner, 1995; Verkhratsky and Kettenmann, 1996).

Gramicidin-perforated-patch recordings in combination with fura-2 AM digital imaging disclosed several types of $\left[\mathrm{Ca}^{2+}\right]_{i}$ changes in cultured cerebellar astrocytes. In a subpopulation of cells, polyphasic changes in $\left[\mathrm{Ca}^{2+}\right]_{i}$ were prominent and were characterized by two to eight transient rises in $\left[\mathrm{Ca}^{2+}\right]_{i}$ and a simultaneous increase in the $\left[\mathrm{Ca}^{2+}\right]_{\mathrm{i}}$ baseline. In a small group of cells $(<10)$ glutamate application resulted in an initial transient rise of $\left[\mathrm{Ca}^{2+}\right]_{i}$ that was followed by a sustained plateau reflecting the averaged oscillatory response of a group of cells that closely resembled the response pattern reported recently for a large group of cells $(>20)$ (Brune and Deitmer, 1995). The nonoscillatory increase in baseline $\mathrm{Ca}^{2+}$ might be caused by a $\mathrm{Ca}^{2+}$ influx through $\mathrm{Ca}^{2+}$-permeable AMPA receptors that are expressed in cultured rat cerebellar astrocytes (Telgkamp et al., 1996). 

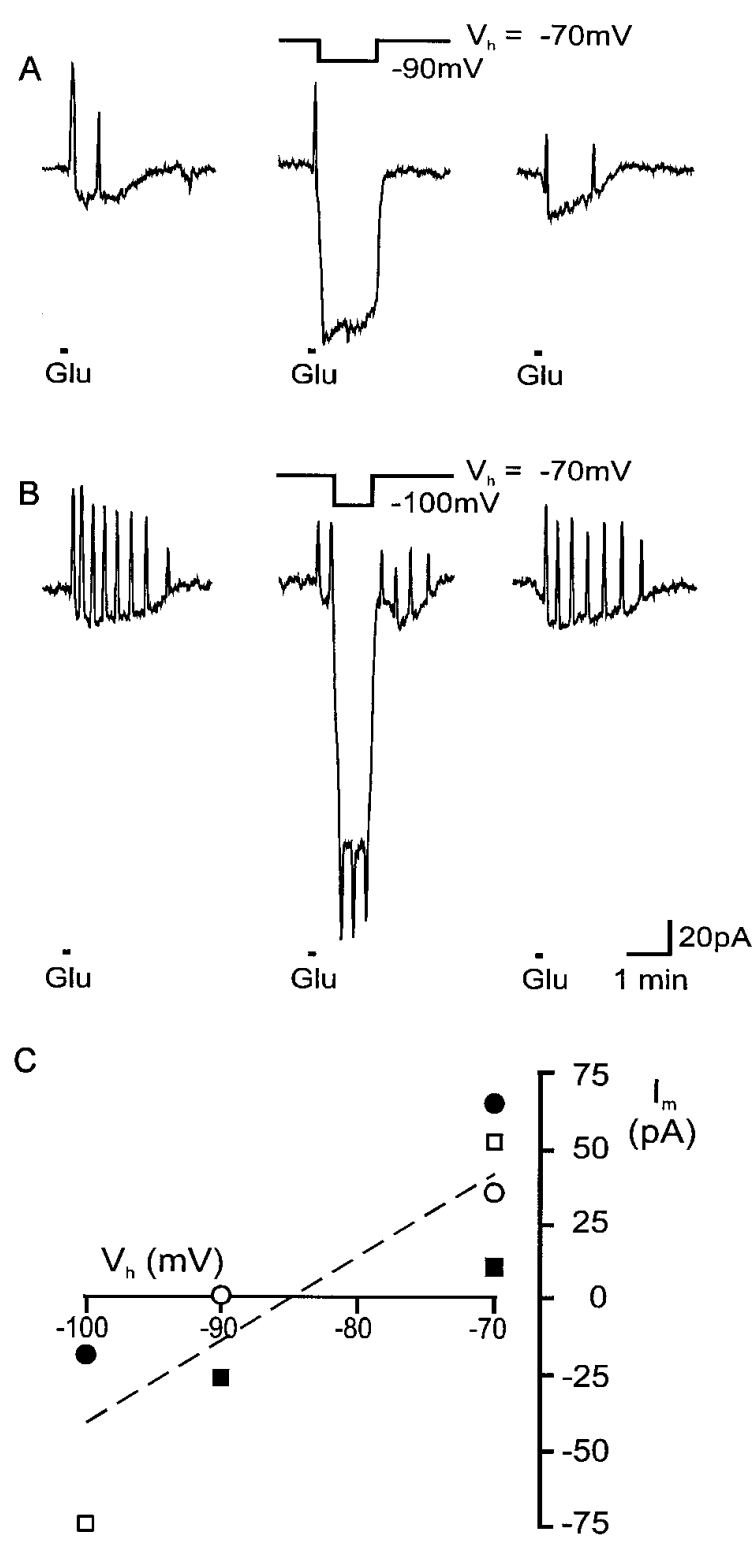

Figure 8. Determination of the reversal potential of glutamate-evoked outward current transients. When the holding potential was changed during a glutamate-induced current response from -70 to $-90 \mathrm{mV}(A)$ or from -70 to $-100 \mathrm{mV}(B)$ as indicated, the outward current transients reversed their polarity. $C$, The current amplitude of glutamate-induced current oscillations was plotted as a function of the membrane potential. To estimate the reversal potential of the current transients, all data points were fitted by linear regression (reversal potential: $-84.9 \mathrm{mV} ; n=4$; the different symbols represent the different cells).

In another subpopulation of cerebellar astrocytes, glutamate induced an initial transient rise that was followed by a plateau without showing distinct oscillations (Fig. 3). In these cells the initial increase in $\left[\mathrm{Ca}^{2+}\right]_{i}$ might have been insufficient to induce subsequent oscillations; however, the response type of glutamateinduced $\left[\mathrm{Ca}^{2+}\right]_{i}$ changes strongly depends on the mGluR subtype. In stably transfected cell lines expressing recombinant receptors of the mGluR $1 \alpha$ subtype, monophasic changes in $\left[\mathrm{Ca}^{2+}\right]_{\mathrm{i}}$ were observed, whereas in cells expressing the mGluR5a subtype, oscillatory responses with an increasing number of $\left[\mathrm{Ca}^{2+}\right]_{\mathrm{i}}$ transients were found (Kawabata et al., 1996). Therefore, different populations of cerebellar astrocytes might exist: one population
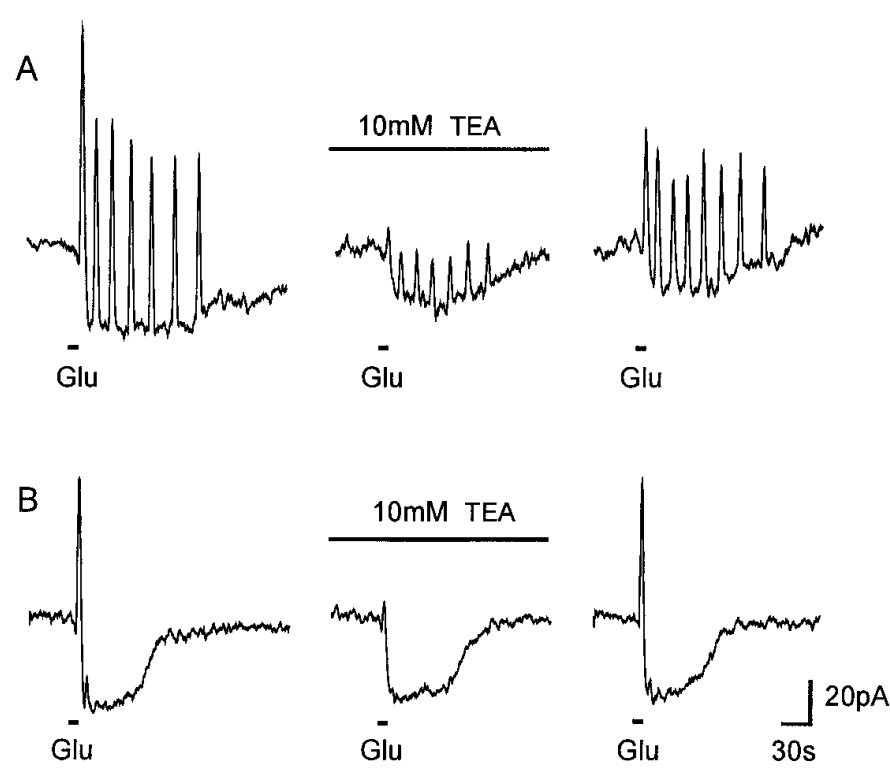

Figure 9. The effect of TEA on glutamate-induced outward current transients. TEA (10 mM, preapplied for $5 \mathrm{~min}$ ) reduced the glutamateinduced outward current transients in cerebellar astrocytes expressing multiple current oscillations $(A)$ as well as a single current oscillation $(B)$, indicating that they were mediated by $\mathrm{K}^{+}$channels.

expressing primarily the mGluR $1 \alpha$ subtype and another the mGluR5a subtype.

\section{Glutamate-induced changes in $\mathbf{p H}_{\mathbf{i}}$}

Intracellular acidifications induced by glutamate were small and non-oscillatory and therefore could not be correlated to either the current or the $\left[\mathrm{Ca}^{2+}\right]_{\mathrm{i}}$ oscillations. The $\mathrm{pH}_{\mathrm{i}}$ measurements might have been impaired by the $\mathrm{H}^{+}$permeability of the gramicidin pores (Myers and Haydon, 1972), which could have caused a dampening of the $\mathrm{pH}_{\mathrm{i}}$ changes. The mechanisms of this acidification are discussed elsewhere (Brune and Deitmer, 1995; Rose and Ransom, 1996; Deitmer and Schneider, 1997).

\section{Is there a link between $\left[\mathrm{Ca}^{2+}\right]_{i}$ and outward current oscillations?}

The $\left[\mathrm{Ca}^{2+}\right]_{\mathrm{i}}$ oscillations observed in the astrocytes likely induced the outward current oscillations, because (1) the number of $\mathrm{Ca}^{2+}$ oscillations always exactly matched the number of outward current transients (Fig. 2) and (2) the $\mathrm{Ca}^{2+}$ oscillations always started shortly before the corresponding outward current transient, suggesting that an increase of $\left[\mathrm{Ca}^{2+}\right]_{\mathrm{i}}$ directly caused the current transients. Because the outward current transients were blocked by TEA and reversed close to the estimated $\mathrm{K}^{+}$equilibrium potential, we conclude that they were mediated by $\mathrm{Ca}^{2+}$ dependent $\mathrm{K}^{+}$channels.

The withdrawal of extracellular $\mathrm{Ca}^{2+}$ did not affect the initial outward current transient in most astrocytes, suggesting that it was mediated by an intracellular $\mathrm{Ca}^{2+}$ release. In addition, maintained oscillatory outward current transients required the presence of extracellular $\mathrm{Ca}^{2+}$. Recent findings have indeed shown that the initial transient rise in $\left[\mathrm{Ca}^{2+}\right]_{\mathrm{i}}$ was mediated by an intracellular $\mathrm{Ca}^{2+}$ release and that the sustained $\left[\mathrm{Ca}^{2+}\right]_{\mathrm{i}}$ oscillations required the presence of extracellular $\mathrm{Ca}^{2+}$ (Cornell-Bell et al., 1990; Glaum et al., 1990; Jensen and Chiu, 1990; de Barry et al., 1991; Holzwarth et al., 1994; Kim et al., 1994; Brune and Deitmer, 1995). In contrast, nonglutamate-evoked oscillations in 
$\left[\mathrm{Ca}^{2+}\right]_{\mathrm{i}}$ also persisted in the absence of extracellular $\mathrm{Ca}^{2+}(\mathrm{me}-$ chanical stimulation: Charles et al., 1991; $\mathrm{P}_{2 \mathrm{Y}}$-purinergic stimulation: Kastritsis et al., 1992); however, it cannot be discounted that the reduction of oscillatory outward current transients was attributable to a depletion of intracellular $\mathrm{Ca}^{2+}$ stores caused by the withdrawal of extracellular $\mathrm{Ca}^{2+}$.

Kainate did not induce current oscillations, although it did evoke distinct changes in $\left[\mathrm{Ca}^{2+}\right]_{i}$ in astrocytes (Enkvist et al., 1989; Jensen and Chiu, 1990, 1991; Holzwarth et al., 1994; Brune and Deitmer, 1995). A monophasic increase in $\left[\mathrm{Ca}^{2+}\right]_{i}$, however, would give rise to a monophasic $\mathrm{Ca}^{2+}$-activated $\mathrm{K}^{+}$current. Therefore, the kainate-induced current represents the sum of a large inward current through kainate-activated AMPA receptor/ channels and a $\mathrm{K}^{+}$outward current. Perforated-patch recordings in hilar glial precursor cells in situ in acute hippocampal slice preparations have shown that kainate could also induce biphasic current responses that were composed of an AMPA receptor/ channel-mediated inward current and a subsequent delayed $\mathrm{Ca}^{2+}$-activated $\mathrm{K}^{+}$current (Backus et al., 1995).

This is the first report of glutamate-induced current oscillations in glial cells. Glutamate-induced depolarizations of the membrane potential have been reported previously in cultured rat brain astrocytes (Bowman and Kimelberg, 1984; Kettenmann et al., 1984) and were attributed to the activation of non-NMDA receptors (Backus et al., 1989). In these studies the changes in membrane potential were measured with sharp intracellular microelectrodes, which should not affect $\left[\mathrm{Ca}^{2+}\right]_{i}$ transients. Although our experimental conditions are comparable, none of these studies has shown any oscillatory changes in membrane potential after glutamate application. In cultured cortical rat astrocytes, however, quisqualate induced biphasic changes in membrane potential (compare Fig. $1 C$ of Backus et al., 1989), characterized by an initial transient hyperpolarization and a delayed depolarization mediated by non-NMDA receptors. Moreover, oscillations of the membrane potential were observed in glial cells of rat hippocampal slices (Walz and MacVicar, 1986) and in astrocytes of kainic acid-lesioned hippocampal slices after the application of a phorbol ester (MacVicar et al., 1987).

Oscillatory changes in $\left[\mathrm{Ca}^{2+}\right]_{i}$ can spread across the glial syncytium like waves (cf. Finkbeiner, 1995) and thus by activation of $\mathrm{Ca}^{2+}$-activated $\mathrm{K}^{+}$channels could give rise to wave-like changes of the glial membrane potential. In astrocytes such potential waves could arise at sites of increased neuronal activity, where an elevation of the extracellular $\mathrm{K}^{+}$concentration and the exposure to glutamate depolarize the membrane potential and evoke an increase in $\left[\mathrm{Ca}^{2+}\right]_{\mathrm{i}} . \mathrm{K}^{+}$uptake into the astrocytic syncytium could travel in phase with a hyperpolarizing potential wave, thus providing spatial dynamics to the glial $\mathrm{K}^{+}$buffer capacity.

\section{REFERENCES}

Abe T, Sugihara H, Nawa H, Shigemote R, Mizuno N, Nakanishi S (1992) Molecular characterization of a novel metabotropic glutamate receptor mGluR5 coupled to inositol phosphate $/ \mathrm{Ca}^{2+}$ signal transduction. J Biol Chem 267:13361-13368.

Aramori I, Nakanishi S (1992) Signal transduction and pharmacological characteristics of a metabotropic glutamate receptor, mGluR1, in transfected CHO cells. Neuron 8:757-765.

Backus KH, Berger T (1995) Developmental variation of the $\mathrm{Ca}^{2+}$ permeability of AMPA receptors in hilar glial precursor cells. Pflügers Arch 431:244-252.

Backus KH, Kettenmann H, Schachner M (1989) Pharmacological characterization of the glutamate receptor in cultured astrocytes. J Neurosci Res 22:274-282.
Backus KH, Elsen FP, Berger T (1995) Secondary effects of kainate in glial cells. Verh Dtsch Zool Ges 88.1:3.

Berger T, Walz W, Schnitzer J, Kettenmann H (1992) GABA- and glutamate-activated currents in glial cells of the mouse corpus callosum slice. J Neurosci Res 31:21-27.

Berridge MJ, Irvine RF (1989) Inositol phosphates and cell signaling. Nature 341:197-205.

Bowman CL, Kimelberg HK (1984) Excitatory amino acids directly depolarize rat brain astrocytes in primary culture. Nature 311:656-659.

Brune T, Deitmer JW (1995) Intracellular acidification and $\mathrm{Ca}^{2+}$ transients in cultured rat cerebellar astrocytes evoked by glutamate agonists and noradrenaline. Glia 14:153-161.

Brune T, Fetzer S, Backus KH, Deitmer JW (1994) Evidence for electrogenic sodium-bicarbonate cotransport in cultured rat cerebellar astrocytes. Pflügers Arch 429:64-71.

Burnashev N, Khodorova A, Jonas P, Helm PJ, Wisden W, Monyer H, Seeburg PH, Sakmann B (1992) Calcium-permeable AMPA-kainate receptors in fusiform cerebellar glial cells. Science 256:1566-1570.

Charles AC, Merrill JE, Dirksen ER, Sanderson MJ (1991) Intercellular signaling in glial cells: calcium waves and oscillations in response to mechanical stimulation and glutamate. Neuron 6:983-992.

Chen J, Backus KH, Deitmer JW (1997) Glutamate evokes intracellular calcium transients and $\mathrm{K}^{+}$current oscillations in cultured rat astrocytes. Proceedings of the 25nd Göttingen Neurobiology Conference, Vol II (Elsner N, Wässle H, eds), p 880. Stuttgart: Thieme Verlag.

Cornell-Bell AH, Finkbeiner SM, Cooper MS, Smith SJ (1990) Glutamate induces calcium waves in cultured astrocytes: long-range glial signaling. Science 247:470-473.

Dani JW, Chernjavsky A, Smith SJ (1992) Neuronal activity triggers calcium waves in hippocampal astrocyte networks. Neuron 8:429-440.

de Barry J, Ogura A, Kudo Y (1991) $\mathrm{Ca}^{2+}$ mobilisation in cultured rat cerebellar cells: astrocytes are activated by t-ACPD. Eur J Neurosci 3:1146-1154.

Deitmer JW, Schneider HP (1997) Intracellular acidification in the leech giant glial cell induced by glutamate and aspartate. Glia 19:111-122.

Enkvist MOK, Holopainen I, Akerman KEO (1989) Glutamate receptor-linked changes in membrane potential and intracellular $\mathrm{Ca}^{2+}$ in primary rat astrocytes. Glia 2:397-402.

Finkbeiner SM (1995) Modulation and control of intracellular calcium. In: Neuroglia (Kettenmann H, Ransom BR, eds), pp 273-288. New York: Oxford UP.

Fischer G (1984) Growth requirements of immature astrocytes in serum-free hormonally defined media. J Neurosci Res 12:543-552.

Glaum SR, Holzwarth JA, Miller RJ (1990) Glutamate receptors activate $\mathrm{Ca}^{2+}$ mobilization and $\mathrm{Ca}^{2+}$ influx into astrocytes. Proc Natl Acad Sci USA 87:3454-3458.

Hamill OP, Marty A, Neher E, Sakmann B, Sigworth FJ (1981) Improved patch-clamp techniques for high-resolution current recording from cells and cell-free membrane patches. Pflügers Arch 391:85-100.

Holzwarth JA, Gibbons SJ, Brorson JR, Philipson LH, Miller RJ (1994) Glutamate receptor agonists stimulate diverse calcium responses in different types of cultured rat cortical glial cells. J Neurosci 14:1879-1891.

Honoré T, Davies SN, Drejer J, Fletcher EJ, Jacobsen P, Lodge D, Nielsen FE (1988) Quinoxalinediones: potent competitive nonNMDA glutamate receptor antagonists. Science 241:701-703.

Jabs R, Kirchhoff F, Kettenmann H, Steinhäuser C (1994) Kainate activates $\mathrm{Ca}^{2+}$-permeable glutamate receptors and blocks voltage-gated $\mathrm{K}^{+}$currents in glial cells of mouse hippocampal slices. Pflügers Arch 426:310-319.

Jensen AM, Chiu SY (1990) Fluorescence measurement of changes in intracellular calcium induced by excitatory amino acids in cultured cortical astrocytes. J Neurosci 10:1165-1175.

Jensen AM, Chiu SY (1991) Differential intracellular calcium responses to glutamate in type 1 and type 2 cultured brain astrocytes. J Neurosci 11:1674-1684.

Kastritsis CHC, Salm AK, McCarthy K (1992) Stimulation of $\mathrm{P}_{2 \mathrm{Y}}$ purinergic receptor on type 1 astroglia results in inositol phosphate formation and calcium mobilization. J Neurochem 58:1277-1284.

Kawabata S, Tsutsumi R, Kohara A, Yamaguchi T, Nakanishi S, Okada M (1996) Control of calcium oscillations by phosphorylation of metabotropic glutamate receptors. Nature 383:89-92.

Kettenmann H, Backus KH, Schachner M (1984) Aspartate, glutamate and $\gamma$-aminobutyric acid depolarize cultured astrocytes. Neurosci Lett 52:25-29. 
Kim WT, Rioult MG, Cornell-Bell AH (1994) Glutamate-induced calcium signaling in astrocytes. Glia 11:173-184.

Kirchhoff F, Kettenmann H (1992) GABA triggers a $\left[\mathrm{Ca}^{2+}\right]_{\mathrm{i}}$ increase in murine precursor cells of the oligodendrocyte lineage. Eur $\mathbf{J}$ Neurosci 4:1049-1058.

Korn SJ, Marty A, Connor JA, Horn R (1991) Perforated patch recording. In: Electrophysiology and microinjection (Conn PM, ed), pp 364373. San Diego: Academic.

Kyrozis A, Reichling DB (1995) Perforated-patch recording with gramicidin avoids artifactual changes in intracellular chloride concentration. J Neurosci Methods 57:27-35.

MacVicar BA, Crichton SA, Burnard DM, Tse FWY (1987) Membrane conductance oscillations in astrocytes induced by phorbol ester. Nature 329:242-243.

Müller T, Möller T, Berger T, Schnitzer J, Kettenmann H (1992) Calcium entry through kainate receptors and resulting potassium-channel blockade in Bergmann glial cells. Science 256:1563-1566.

Myers VB, Haydon DA (1972) Ion transfer across lipid membranes in the presence of gramicidin A. II. The ion selectivity. Biochim Biophys Acta 274:313-322.

Nakanishi S (1992) Molecular diversity of glutamate receptors and implications for brain functions. Science 258:597-603.

Nedergaard M (1994) Direct signaling from astrocytes to neurons in cultures of mammalian brain cells. Science 263:1768-1771.

Perkins MN, Stone TW (1982) An iontophoretic investigation of the actions of convulsant kynurenines and their interaction with the endogenous excitant quinolinic acid. Brain Res 247:184-187.

Pin JP, Duvoisin R (1995) The metabotropic glutamate receptors: structure and functions. Neuropharmacology 34:1-26.

Quandt FN, MacVicar BA (1986) Calcium activated potassium channels in cultured astrocytes. Neuroscience 19:29-41.

Rose CR, Ransom BR (1996) Mechanisms of $\mathrm{H}^{+}$and $\mathrm{Na}^{+}$changes induced by glutamate, kainate, and D-aspartate in rat hippocampal astrocytes. J Neurosci 16:5393-5404.

Rudy B (1988) Diversity and ubiquity of K channels. Neuroscience 25:729-749.

Salm AK, McCarthy KD (1990) Norepinephrine-evoked calcium transients in cultured cerebral type 1 astroglia. Glia 3:529-538.

Seifert G, Steinhäuser C (1995) Glial cells in the mouse hippocampus express AMPA receptors with an intermediate $\mathrm{Ca}^{2+}$ permeability. Eur J Neurosci 7:1872-1881.

Sontheimer H, Kettenmann H, Backus KH, Schachner M (1988) Glutamate opens $\mathrm{Na}^{+} / \mathrm{K}^{+}$channels in cultured astrocytes. Glia 1:328-336.

Stelzer A, Kay AR, Wong RKS (1988) $\mathrm{GABA}_{\mathrm{A}}$-receptor function in hippocampal cells is maintained by phosphorylation factors. Science 241:339-341.

Tanabe Y, Nomura A, Masu M, Shigemoto R, Mizuno N, Nakanishi S (1993) Signal transduction, pharmacological properties, and expression patterns of two rat metabotropic glutamate receptors, mGluR3 and mGluR4. J Neurosci 13:1373-1378.

Telgkamp P, Backus KH, Deitmer JW (1996) Blockade of AMPA receptors by nickel in rat astrocytes. Glia 16:140-146.

Usowicz MM, Gallo V, Cull-Candy SG (1989) Multiple conductance channels in type- 2 cerebellar astrocytes activated by excitatory amino acids. Nature 339:380-383.

Verkhratsky A, Kettenmann H, (1996) Calcium signaling in glial cells. Trends Neurosci 19:346-352.

Walz W, MacVicar BA (1986) Electrophysiological properties of glial cells: comparison of brain slices with primary cultures. Brain Res 443:321-324.

Wyllie DJA, Cull-Candy SG (1994) A comparison of non-NMDA receptor channels in type-2 astrocytes and granule cells from rat cerebellum. J Physiol (Lond) 475:95-114. 